\title{
8 Reclaiming tradition as critique of oppression
}

\author{
Teresa Callewaert
}

This chapter ${ }^{1}$ sets out to discuss if, why, and how theology should be used for critique of and resistance to oppression. I will do this through an engagement with two thinkers from the beginnings of what in Christian tradition has been referred to as liberation theology, but which, for the purpose of treating both Islamic and Christian thought, could be more aptly called liberationism. ${ }^{2}$ The idea is, through such an engagement, to identify some of the reasons these early thinkers had for choosing theological tools for their resistance and to analyse their strategies. I will then move on to a couple of contemporary thinkers who have also chosen to articulate resistance to oppression through theological thought, and try to sketch how certain tendencies evident in the early stages of liberationism have renewed relevance for our current world.

When Gustavo Gutiérrez, the Peruvian theologian and priest who was one of the first people to put Catholic liberation theology into writing, wrote $A$ Theology of Liberation in 1971, it was in the firm belief that Christian faith and theology represented a tremendously important resource in the struggle for human dignity and liberation, a struggle which to him involved a critique of, and revolution against, the power of global capitalism. ${ }^{3}$ At roughly the same time, in an Iran ruled by the authoritarian regime of the Shah, Ali Shariati, a Shiite Muslim public intellectual and mystic, developed ideas about Islam being the only viable force for resisting the blatant oppression and exploitation of capitalism and imperialism. ${ }^{4}$

There are important similarities between their approaches; most notably for our discussion today, they have similar reasons for involving theology in the struggle against oppression. To them, theology, or religious tradition more generally, is a vehicle for conscientisation. That is, it can create awareness of oppression, of the possibility of another world, and mobilise people for the struggle. There are several reasons why theology can fulfil this task, which can be roughly divided into two sets.

The first set of reasons centres around the fact that theology, or religious tradition, is the tradition of the poor. This means that it is a tradition to which the people already belong. A struggle starting from that tradition uniquely restores the poor's confidence in themselves and in what belongs to 
them. In contrast to other modes of thought prevalent at the time - developmentalist, Marxist, capitalist - religious tradition is something the poor can claim as their own. By starting from such a tradition, mobilisation can be free from condescension, and can therefore build self-reliance, independence, and a sense of identity. Reliance on tradition is, to Shariati and Gutiérrez, empowering. Moreover, tradition represents a kind of entry point for awareness. Because it is something already familiar and close to their hearts, its revolutionary content can be discovered by the poor as something in a sense already embraced and believed, although not consciously so. This is the meaning of Gutiérrez's concept of conscientising evangelisation. The starting point in tradition makes the revolutionary message fundamentally legitimate and believable to the poor.

But there is another set of reasons for relying on tradition when resisting oppression, on which the first set of reasons depend. In order for theology to fulfil a conscientising role, it must also in and of itself be morally and philosophically viable and adequate for the task; that is, it must contain insights and knowledge that are valuable to such a struggle. The claim made by both Gutierrez and Shariati is that theology has such a content, and indeed that, when properly understood, it contains unique insights with relevance for the resistance. The three central insights that theology delivers according to both Shariati and Gutiérrez, although in slightly different ways, are these:

1 That God considers the poverty that people live in to be an abomination. Shariati makes this argument by relying on the doctrine of tawhid. This is one of the most important - one could claim the most fundamental - doctrine of Islamic thought: the oneness of God. Because God is one, humanity is called to mirror this oneness through equality and social justice. Since there is but one God, all of the world belongs to God, the material world no less than the spiritual. This means that God is concerned with the realisation of human dignity in material terms, and that poverty is a kind of blasphemy. ${ }^{5}$ Gutiérrez develops his argument from creation, also highlighting the importance of material realities: God has created the world, and the world in its material aspects is of concern to God. Moreover, God created human beings in his image and with the intention that humans should have life in abundance. Poverty constitutes a defilement of the face of God, because the image of God, given in creation and confirmed in the incarnation of Christ, is sullied. The incarnation, God taking flesh, teaches us to see God in our neighbour and to abhor the destitution of the poor. ${ }^{6}$

2 That the cause of poverty is exploitation and oppression. For both Gutiérrez and Shariati, this point leads to a critique of theologies and religious authorities that describe poverty as either natural and inevitable, or lamentable but sorting itself out. Such theologies legitimise poverty by obfuscating its origin, and should, according to these writers, be understood as part of and serving oppressive structures. 
Shariati speaks with condemnation of the spread of ignorance, quietism, and superstition among the conservative religious authorities of his day. The ulama, i.e. those learned in traditional Islamic sciences, betrayed the trust put in them by the people. Instead of preaching the Islam of resistance, he claimed that they encouraged conservatism and withdrawal from political life. ${ }^{7}$ Gutiérrez criticises hierarchical church structures and theologies that legitimise those in power. The church, in his view, should be a church that is poor and stands with the poor. In the particular situation in Latin America of his day, the church must take a stand against power in order to break with an age-old complicity with the rich and the powerful. Gutiérrez claims that its legacy of legitimising power puts the church in a position where it must visibly choose the other side so as not to lapse into a silent assent to the status quo. That means speaking the truth about the nature of exploitation, and turning away from theologies that treat poverty as a normal state of affairs. Both Shariati and Gutiérrez thus attack both theology's political quietism and the theological distinction between spiritual and material that underpins it. ${ }^{8}$

3 That the poor are able to become subjects of their history and successfully fight exploitation and oppression, and change their world. Shariati claims that the liberation of the oppressed is promised by God in the Quran - that at the very core of Islamic faith is its revolutionary spirit. The oneness of God means that human beings are subordinate to no one but God, and that they are free to revolt against all despotic or authoritarian powers. Muslims have a unique source of hope and confidence because they know that God is always on the side of the oppressed and that victory is promised by God to every group which struggles for its rights. ${ }^{9}$ For Gutiérrez, the theological figure of the kingdom of God plays a vital role in explaining the position he takes on struggle. Faith in the kingdom, Gutiérrez claims, shows the provisional character of any human order. Nothing that is built by humans is everlasting, oppressive orders included. Although the obstacles might seem insurmountable, the struggle for justice is possible because it is sustained by the gratuitousness of God, closely connected to the freedom of God which makes possible what to humans is unforeseeable. ${ }^{10}$ The works of solidarity and the struggle for justice must be practised with humility, because the kingdom of God always goes beyond what humans can achieve and imagine. But it can also be practised with hope, because the kingdom is present in and enables the temporal processes of liberation.

These three insights - that poverty is an abomination, that its cause is exploitation and oppression, and that the poor can successfully fight the oppression to which they are subject - are all contained in their respective religious traditions as Shariati and Gutiérrez understand them. But more than that, these insights receive their urgency from the fact that they are 
insights about what God wants for humanity, and thus insights of ultimate importance for believers.

Gutiérrez calls the tasks of theology denunciation and annunciation. The church is called to denounce the present conditions of oppression and injustice and announce the good news of God's love, the coming of the kingdom and the task of furthering God's purposes in the present through the struggle against degradation of his creations. In Gutiérrez's understanding, the whole truth about human liberation, the nature of sin, and the nature of salvation is available only in Christ. ${ }^{11}$

Shariati understands Islam as an ideology, in the Gramscian sense of a worldview that can demystify oppressive relations and make resistance possible. ${ }^{12}$ In Shariati's understanding, Islam is in fact the most powerful resource against oppression and colonialism. It is a tool of critique and analysis of both society and religion, a lens through which the world is understood and can be changed. Shariati claims that concepts such as oppression, justice, and righteous leadership receive their most lucid articulations in Islamic tradition. Through Islam as a worldview, critique of the injustice of society as well as visions about an alternative order can be articulated. ${ }^{13}$

It might be interesting enough to dwell on this comparison. One could discuss the reasons for the similarities in the Zeitgeist of these two writers, a time imbued with ideas from the Bandung conference, the revolution in Cuba, the non-aligned movement, and so on. As examples of contextual theologies, the works of Gutiérrez and Shariati are interesting because the context of oppression, poverty, and struggle is formulated and openly dealt with. This is often highlighted in discussions about what I have called liberationism. The designation "contextual" should, however, be problematised, given that their theology is no more contextual than any other. One could easily claim, starting from the very similarity between their approaches, that liberationist thought was, at least at the time, remarkably universal and more global, in its explanatory power and ability to resonate with experience, than what was produced at seminars in Europe at that time. Furthermore, what makes their contribution interesting is precisely the fact that they claim not only to articulate what their tradition is about in a particular time and place, but rather to impart something belonging to the very core of that tradition without which it would lose its soul.

A comparison of these writers also brings into focus what traditions can bring to reasoning as an endeavour. There are important differences in their thoughts, despite the similarities in context and political thrust. These intricate patterns of particularities can be analysed and shown to arise from how different resources in the respective traditions are actualised when resistance to capitalism is articulated through them. ${ }^{14}$

Something about how theology matters to the entire understanding of a particular political problem can be gauged from how these writers wrestle with their respective traditions in their particular contexts, understood not only as time and place and political situation, but more importantly as the 
texts, practices, beliefs, and reasons that make up the context of theological thought within a particular tradition. Such questions could be productively treated by delving deeper into, for example, Gutiérrez's understanding of the incarnation as the act that completes and universalises the bond between God and the neighbour, such that every act in the secular realm can be defined as an act toward Christ as we meet him in the face of the destitute..$^{15}$

In Shariati, a vital role is rather played by the central dogma of tawhid, the oneness of God, in criticising all spiritualisation of religion and insisting on the necessity of understanding God's justice to concern the material world of the here and now. While these writers are, in many ways, situated in similar contexts historically and socially, and arguing for similar politics, they do so by working with something quite central to their respective traditions' theology. And conversely, the things they have to struggle with, to redefine or explicate in new ways, also depend on the elements of their tradition that are central enough to demand answers from their perspective. Thus, Gutiérrez struggles with the ideal of poverty in Catholic tradition, which leads him to redefine evangelical poverty as solidarity with the poor, in order to be able to condemn material poverty as against God's purposes. ${ }^{16}$ Shariati wrestles with the interpretation of religious practices and duties and defines them as requiring a responsible subject with adequate resources. In Shariati's understanding, spirituality is understood as closely connected to morality, and morality requires solidarity with and fulfilment of duties to the poor. Because you need to have in order to be able to give, he can articulate the material welfare of the believer as the foundation of spirituality and a prerequisite for giving an account of oneself on the day of judgement. A person's dignity requires the means to show solidarity to others. ${ }^{17}$

However, one might also ask, who cares? If the understanding of Christ or of tawhid was once a matter of life and death, or at least something to which people partaking in political reflection and practice were expected to be able to relate, today it might seem as though these questions are marginal footnotes in the discussions of increasingly irrelevant religious organisations and some weird people in academia. One could, of course, argue that this is not globally the case - that in the world outside supposedly secular Northwestern Europe religion as a motivating and legitimising force is not only alive but thriving. But in the context of contextual theology of Sweden, home of the religiously illiterate? One could argue that, increasingly, the rest of the world is here too, both materially and digitally. One could argue that the forces of darkness, of nationalist chauvinism and closed borders, are making a grab for the local religious heritage and we would do well not to retreat from the battlefield.

There is an even better reason, however. Even if the first set of assumptions of Shariati and Gutiérrez - the ones about theology being the primary language of the oppressed and destitute, uniquely positioned to raise awareness and instil confidence - do not hold and are not relevant in our context, I would claim that the second set of assumptions - the ones about insights 
to be had from theological reflection - are still worth taking seriously. Theology still offers particular insights. Perhaps these are not in each and every case the most lucid, but nonetheless, they enable us to see things we did not before. Theological articulations of human life as profoundly social and creative, for example, might be needed to counter increasingly utility-centred understandings of human beings. Accounts of the dignity of the person as envisioned by the Enlightenment, resting on a particular ability such as rationality, are increasingly in trouble, and might need anchoring in ideas of being redeemed and loved, or being responsible on the day of judgement.

The case for theology as a resource for resistance is strengthened, I believe, by the realisation of postmodern philosophy of the impossibility of drawing sharp boundaries between secular and religious thought, but even more so by the insight that there is no view from nowhere. There is no outside, from which we can look in on the world and prescribe remedies.

This might mean that we need traditions in order to be able to think at all, and that traditions are not mere vehicles or empty vessels to be filled with the same original or purely human content. Traditions are avenues for thought; they are methods through which we proceed painfully and piecemeal, to discover something about being human, about justice, truth, and God. Because traditions are contingent, messy, beautiful, and complicated, and not at all alike, it is a dangerous position to limit one's partners in conversation and solidarity to one or a couple of ones that are related, say the traditions of Enlightenment, liberalism, secular humanism, and human rights.

But, in order for traditions to fulfil this role, as avenues for thought, through which conceptual resources are developed by which we can articulate critique, there might be a need to revisit the starting points of theologies of liberation. I would claim that there are at least two such starting points.

In the writings of Gutiérrez and Shariati, and in theologies aspiring to liberation generally, I would claim that there is sometimes a tendency to place oneself outside tradition as its critic, relying on tools from, for example, Marxist, feminist, or queer theory. Perhaps this should rather be termed to place oneself beside tradition, since we just concluded that one is never outside tout court - one is always assuming some kind of vantage point. From the perspective of tradition, however, one is outside.

This tendency to assume an outside starting point is manifested in Gutiérrez's use of some aspects of social theory of Marxist varieties. While nowhere near as indiscriminate as the Congregation of the Doctrine of the Faith claimed, ${ }^{18}$ the use of such theories is nevertheless not in every instance justified by tradition. I am not saying that such justification would not be possible. I am merely pointing out that while Gutiérrez takes great care to show how the aspirations of the poor and of liberation theology are firmly anchored in the Gospel's ideas such as the preferential love of God for the poor, he does not perform the same justification when it comes to the Marxist view of the laws of history, and so on. 


\section{2}

Meanwhile, in Shariati's writings, there is a tendency to bypass Islamic figh, i.e. the rich heritage of jurisprudence that represents the development of historical interpretations of Sharia in various law schools and historically influential thinkers. Instead, Shariati often goes directly to the Quran, the Sunna (the example of the Prophet), and the popular traditions surrounding the first Muslims, the Companions of the Prophet. This in a sense had become a traditional move for Muslim reformers in his day, common among the thinkers of the Islamic renaissance of the turn of the previous century. However, it is also a move that conceives of much of tradition as a problem and an encumbrance to be discarded, rather than a resource. As a strategy, it can endanger the perceived identity and authority of the interpreter.

However, there is also in both writers the inverse impulse - to place themselves squarely inside tradition, insisting that the tools of tradition itself are sufficient to develop a theology that is truly liberating, without sacrificing any claims to identity or belonging, indeed claiming to represent a more orthodox position than conservative religion. Assuming a position that reclaims tradition does not necessarily entail accepting the limits and boundaries of tradition, but rather accepting that one has to constructively relate to such limits, even while transgressing limits or pushing boundaries further. This can be done by reinterpreting tradition through quite regular and orthodox interpretative methods of one's tradition, maybe expanding them but with recourse to justifications that derive their authority from inside tradition itself.

In the case of Shariati, it is important to both him and his followers that he understands his reinterpretation of Islam as mandated by tradition itself, indeed as an extraction and refinement of hidden resources. He insists that it is by following the imperative of tradition that he has arrived at his radical position. He vindicates his position by using the central Shiite theme of being the defeated, martyred, and consequently hidden religious tradition, and makes a vital dogma of Islam, tawhid, the oneness of God, the supreme vantage point from which to judge what constitutes faithfulness to tradition. ${ }^{19}$

To Gutiérrez, it is the Gospel itself as the good news to the poor that justifies his understanding of what Christian faith entails and the concomitant engagement with struggle for both a more just world and a more just Church. He constantly refers to the workings of the Spirit through quite orthodoxly authoritative channels such as the magisterium of the Second Vatican Council. His notion that theology grows out of a reflection on Christian faith and practice is quite a traditional one; it assumes its specifics in Gutiérrez's account because the practice in question is situated in the struggle for justice. ${ }^{20}$

As remarked by Christian feminist theologian Jenny Daggers, while the very notion of theological orthodoxy is sometimes understood as antithetical to the struggle for liberation, others have remarked that critique of power is in itself a thoroughly orthodox Christian position. ${ }^{21} \mathrm{I}$ believe that the latter tendency, to reclaim tradition, to understand one's reinterpretation as not a 
critique from the outside but rather as a higher order of faithfulness mandated by tradition itself, is the one that also holds out the greatest potential for the context of the religiously illiterate. In a situation where the political position of religious tradition and theological interpretation on any given issue does not immediately and necessarily concern everybody, there is in a way even more reason to insist on giving voice to distinctly theological insights. This is necessary if theology is to contribute to the contemporary critique of oppressive orders, and not just be a cognitive detour ultimately making the same claims as secular critique, although in another language or for another audience, or be confined to supplying motivational force and legitimacy to a struggle we already have decided to be right.

But this in turn requires maintaining confidence in the possibility of reforming tradition through its own tools and methods. If there is no universal rationality that can set standards and be the arbiter between interpretations, plausible methodology and norms of interpretation must be articulated from within traditions. Of course, it is not possible to completely distinguish and separate tools, methods, or interpretative measures as originating outside or inside tradition. Religious traditions of thought have a long history of interaction, overlap, and intermingling with both philosophical and political thought, as well as social movements. Traditions are dynamic, not monolithic, and what is perceived as the centre of tradition or as heresy is constantly undergoing change, even if slowly. While the very concept of tradition implies evolution, traditions are also homes to a certain continuity-in-difference, a directionality that one can aspire to be faithful to without being conservative. For this to be possible, tradition must somehow be respected as an avenue for thought that contains its limitations, methods, concepts, and resources. Not all boundaries need be respected, but they need to be related to in some constructive way that makes their transgression a matter justified by recourse to tradition itself.

In the field of liberation theology today, among feminist theologians, queer theologians, disability theologians, and critics of capitalism, there are aspects of both the approaches that I have identified in my treatment of Shariati and Gutiérrez, although I would say that the strategy to reclaim tradition from the inside is gaining ground. It is present, for example, in the practice of hadith criticism of Muslim feminists such as Amina WadudMushin and Fatima Mernissi, theologians such as Virginia Burrus or Amy Hollywood, and the analysis of the traditions about the Prophet Lut by queer Islamic thinker Scott Siraj Al-Haqq Kugle. ${ }^{22}$

An example which highlights the importance of orthodoxy to the project of reclaiming tradition is queer Catholic theologian James Alison. He deliberately eschews standards and resources from outside tradition such as gay experience or queer theory and relies firmly on Church authority. Alison challenges the Catholic Church's teaching on homosexuality on the basis of the understanding of original sin, grace, and anthropology developed by the Council of Trent of the 16th century. ${ }^{23}$ 
The Tridentine position, according to Alison, entails that human nature is damaged, but not destroyed, by sin. Human desire is intrinsically good, but always and everywhere experienced as accidentally disordered. Desire is not, however, radically corrupt. That was precisely the Reformed position the Council of Trent rejected. Rather, a Catholic understanding is that God's grace gradually transforms and orders desire so that persons are brought to flourishing from where they are. Grace perfects nature; it does not abolish or replace nature. All humans start out with a life that is moved by disordered desire, and all humans can, from within that disordered desire, learn what is good. Importantly, something about what is true and good can be discerned through attention to human desire and what is conducive to human flourishing. ${ }^{24}$

But, Alison claims, the Church's teaching on homosexuality seems to imply that, for homosexual people, there is no relationship between what is desired and what is good. What feels natural is an "inclination that is objectively disordered", and only by complete rejection of what one longs for can one come to know creation. This means, according to Alison, that the Church's anthropology has been fundamentally altered into a de facto Reformed teaching. As such, it treats certain people as incapable of being perfected by grace but rather in need of having their nature abolished. ${ }^{25}$ This is grave because it is a failure of Catholicity. The Church has lost touch with a Catholic understanding of original sin as something that affects everybody but still leaves the person with some insight to be discerned and some desire to be perfected. ${ }^{26}$

Alison understands the interpretative method he uses in relation to Catholic teaching to be justified through the example of Jesus. Through this method, what is currently understood as the orthodoxy of tradition is exposed as being in contradiction to the deepest and most resilient elements of tradition. Such an understanding, claims Alison, challenges us not to break with tradition, but to rediscover and make alive within tradition that which enables the breaking out of the order of the world. ${ }^{27}$

Another good example, which is particularly interesting in relation to Shariati's tendency to bypass Islamic jurisprudence, is Islamic scholar Kecia Ali's insistence that Islamic feminists should reclaim the tradition of fiqh, i.e. jurisprudence as done in the classical Islamic law schools, through traditional methodologies of interpretation. Ali discusses several issues raised by feminists such as marriage, divorce, sex, female genital cutting, and homosexuality. She claims not only that classical jurisprudence should be addressed because its fundamental assumptions continue to affect regulations and mindsets, but also that there are resources in the traditions of classical scholars that can be constructively brought to bear on the dissonance experienced around these issues. ${ }^{28}$

One such resource is precisely the methodological sophistication of classical scholars in relation to the complex and heterogeneous intellectual and textual legacy. According to Ali, jurisprudential methods can offer Muslim 
feminists much because the ways in which jurists have related source texts to social contexts demonstrates that the law they constructed is always already subjected to interpretation. ${ }^{29}$ This interpretive precedent of early jurists can authorise a similar adaptive effort today, which will allow, through a variety of very traditional legal manoeuvres and interpretive devices, a more radical interpretation. The second resource pointed to by Ali is acceptance of divergent perspectives. This is a central feature of classic jurisprudence. In contrast, proponents of progressive politics often make problematically grandiose and sweeping claims about what is Islamic and un-Islamic, which reduce interpretive leeway and minimise attention to complexities and contexts. Ali asks whether it is acceptable and ultimately productive to engage in methodologically problematic oversimplifications for strategic aims. Instead, she advocates a detailed investigation of the layered jurisprudential material, making use of various interpretive measures, such as relying on traditional standards to determine the authority of rulings one wants to challenge. ${ }^{30}$

Alison and Ali can both be understood as continuing the struggle to reclaim tradition for a radical agenda. While their issue is not with global capitalism, they are struggling with the forces of oppression of their contexts, and the theological thought that legitimises such oppression. Their methods resonate with the claim of the early liberationists: a claim to a greater faithfulness toward tradition and a more plausible understanding of its implications than those that generally pass for representatives of the traditional.

Making one's intellectual enterprise dependent on the criteria, methodologies, and concepts internal to a specific tradition can be understood as restricting one's possibilities, as accepting certain limitations. While such limitations are often feared as obstacles to full emancipation, they can also act as bulwarks against a rampant conservatism masquerading as orthodoxy. Moreover, the constraints in themselves constitute possibilities in that they open up certain avenues for thought and enable a certain kind of critical enterprise. The persistent effort to situate one's thought inside tradition by relating to its concepts, using and developing its method, justifying interpretations through its criteria, and justifying one's departures from them or reinterpretations of them with recourse to the motifs and reasons that tradition supplies makes a difference to what one is able to think. Traditions form conditions of thought, which become evident in lingering emphases, directions taken, perspectives adopted, and the specific shape of the solutions to certain intricate problems. This can be understood as tradition's tendency to resist, and might lead to new and surprising things being discovered. A certain stringency of method might be the prerequisite for allowing tradition to exert its resistance, to realise the critical and transformative potential of tradition.

While liberationist efforts will perhaps never reach the point where there is no need for any foothold outside tradition in order to be able to develop 
critique of tradition itself, it is increasingly recognised, precisely in our present conditions, that tradition represents an outside to the horrendous suffering and vacuous uniformity of modern global capitalism, that theological thought can contribute another story about what human life and ultimate purposes are about.

\section{Notes}

1 This chapter is based on a lecture delivered at the Centre of Theology and Religion in Lund, at the conference Liberating Theology - 25 years of Institute for Contextual Theology, Sweden, November 24, 2017.

2 Where not otherwise indicated, I rely in my research on Gutiérrez and Shariati, available in Teresa Callewaert, Theologies Speak of Justice: A Study of Islamic and Christian Social Ethics (Uppsala: ACTA 2017).

3 Gustavo Gutiérrez, A Theology of Liberation: History, Politics and Salvation (Maryknoll: Orbis Books, 1973).

4 Ali Rahnema, An Islamic Utopian: A Political Biography of Ali Shariati (London: I. B. Tauris, 1998).

5 Ali Shariati, What Is to Be Done? The Enlightened Thinkers and an Islamic Renaissance (Houston: IRIS, 1986), 43.

6 Gustavo Gutiérrez, On Job: God Talk and the Suffering of the Innocent (Maryknoll: Orbis Books, 1987), xiii.

7 Ali Shariati, Religion vs. Religion (Chicago: Kazi Publications, 2003), 32-36.

8 Gutiérrez, Theology of Liberation, 266.

9 Shariati, What Is to Be Done? 92-93.

10 Gutiérrez, On Job, 96.

11 Gutiérrez, Theology of Liberation, 105-8, 152.

12 Chantal Mouffe, "Hegemony and Ideology in Gramsci," in Gramsci and Marxist Theory, ed. Chantal Mouffe (London: Routledge and Kegan Paul, 1979), 168-204, 190-93.

13 Shariati, What Is to Be Done? 50-53.

14 On the power of theology to resist (and overcome) capitalism, cf. also Ulrich Duchrow's Chapter 5 and Atola Longkumer's Chapter 6 in this volume.

15 Gutiérrez, Theology of Liberation, 300-1.

16 Ibid., 287-302.

17 Shariati, What Is to Be Done? 23.

18 Congregation for the Doctrine of the Faith, "Ten Observations on the Theology of Gustavo Gutiérrez" (1983) and Congregation for the Doctrine of the Faith, "Instruction on Certain Aspects of the 'Theology of Liberation'" (1984) in Alfred T. Hennelly, ed., Liberation Theology: A Documentary History (Maryknoll: Orbis Books, 1990), 348-50 and 393-414, respectively.

19 Shariati, What Is to Be Done? 22.

20 Gutiérrez, Theology of Liberation, ix.

21 Jenny Daggers, "Girls and Boys Come Out to Play: Feminist Theology and Radical Orthodoxy in Lucid Encounter," in The Poverty of Radical Orthodoxy, eds. Lisa Isherwood and Marko Zlomislic (Eugene: Pickwick, 2012), 97-118, 98.

22 See for example Fatima Mernissi, "A Feminist Interpretation of Women's Rights in Islam," in Liberal Islam: A Sourcebook, ed. Charles Kurzman (Oxford: Oxford University Press, 1998), 112-26; and Amina Wadud-Mushin, "Qur'an and Woman," in Liberal Islam: A Sourcebook, ed. Charles Kurzman (Oxford: Oxford University Press, 1998), 127-38; Virginia Burrus, "Queer Father: Gregory of Nyssa and the Subversion of Identity," in Queer Theology: Rethinking 
the Western Body, ed. Gerard Loughlin (Oxford: Blackwell, 2007), 147-62; and Amy Hollywood, "Queering the Beguines: Mechthild of Magdeburg, Hadewijch of Anvers, Marguerite Porete," in Queer Theology, ed. Gerard Loughlin (Oxford: Blackwell, 2007), 163-75; Scott Siraj Al-Haqq Kugle, Homosexuality in Islam: Critical Reflection on Gay, Lesbian, and Transgender Muslims (Oxford: One World Publications, 2010).

23 James Alison, “The Gay Thing: Following the Still Small Voice," in Queer Theology: Rethinking the Western Body, ed. Gerard Loughlin (Oxford: Blackwell, 2007), 50-62.

24 Ibid., 55-56; James Alison, Faith Beyond Resentment: Fragments Catholic and Gay (New York: Crossroad Publishing, 2001), 226-28.

25 Alison, "The Gay Thing," 57-59.

26 Alison, Faith Beyond Resentment, 96-99.

27 Ibid., 221.

28 Kecia Ali, Sexual Ethics and Islam: Feminist Reflections on Qur'an, Hadith and Jurisprudence (Oxford: One World, 2006), 11-13.

29 Ibid., 154.

30 Ibid., 99-101. 